\title{
ЯКИМ НАВЧАЛЬНО-МЕТОДИЧНИМ МАТЕРІАЛАМ ДЛЯ САМОПДГОТОВКИ ДО ПРАКТИЧНИХ ЗАНЯТЬ НАДАЮТЬ ПЕРЕВАГУ СТУДЕНТИ?
}

Н. А. Ничик

\author{
ДВНЗ “Тернопільський державний медичний університет імені І. Я. Горбачевського МОЗ України”
}

\section{WHAT KINDS OF TEACHING MATERIALS FOR SELF-TRAINING TO PRACTICAL CLASSES DO STUDENTS PREFER?}

\author{
N.A. Nychyk \\ SHEI "Ternopil State Medical University by I. Ya. Horbachevsky of MPH of Ukraine”
}

\begin{abstract}
Вивчено та проаналізовано інформативність навчальних матеріалів для самостійної роботи, розміщених на електронній сторінці кафедри інфекційних хвороб з епідеміологісю, яким під час підготовки до практичних занять надають перевагу студенти 5 та 6 курсів. Встановлено, що студенти 5-го курсу найчастіше працюють з матеріалами до практичних занять і навчальними посібниками, які дозволяють їм оптимально підготуватися до заняття. Студенти 6-го курсу більше користуються матеріалами, що містять наочну інформацію, яка грунтовно закріплюс отримані на попередніх курсах теоретичні знання. Постійна робота студентів з матеріалами, розміщеними на WЕВ-сторінці, вказує на необхідність їх обов'язкового і систематичного інформативного оновлення викладачами.
\end{abstract}

The information content of teaching materials for students' self-training materials to classes, that are represented on Infectious Diseases and Epidemiology Department's electronic page, to which during preparation for practical classes the students of the $5^{\text {th }}$ and $6^{\text {th }}$ course prefering was studied and analyzed. It was determined that the students of the 5-th course often work with the materials to practical classes and tutorials that allow them optimally prepare for classes. Students of the 6-th course use materials that contain visual information that thoroughly reinforces obtained in previous years theoretical knowledge. Persistent students' work with materials placed on the WEB-page, indicates the necessity of the systematic informative updating.

Вступ. Новітні технології стали основним фактором вирішення завдань реформування вітчизняної системи освіти, що проходить у сучасних умовах модернізації освітніх структур, трансформації загальносистемного і комплексного характеру $[1,2]$. Сучасний стан розвитку інформаційного забезпечення відкриває широкі можливості доступу до джерел інформації і тому суттєво зміщує акценти у плануванні навчального процесу в бік самостійної роботи [3]. Отож нині в основу вищої освіти покладено самостійну та індивідуальну роботу студентів. Зростає значущість практичних занять, де розкривається творчий підхід студента, його уміння мислити аналітично, здатність аргументувати і відстоювати власну думку на базі аналізу й синтезу вивченого. Ще одним важливим аргументом збільшення частки самостійної та індивідуальної роботи є той факт, що самостійність розвиває у студента здатність глибше розмірковувати, шукати шляхи вирішення проблем. Ми зосередимо увагу на якості навчальнометодичних матеріалів для самопідготовки студентів до практичних занять у кредитно-модульній системі організації навчального процесу.

Основна частина. Самостійна робота студентів завжди була і $є$ основною складовою частиною у засвоєнні знань з інфектології на кафедрі інфекційних хвороб з епідеміологією ТДМУ ім. І. Я. Горбачевського. Для покращення якості засвоєння теоретичного матеріалу під час підготовки до практичних занять педагогічний колектив кафедри опрацьовує велику кількість наукових джерел, розробляє достатню кількість матеріалів для підготовки до лекцій, практичних занять, методичних рекомендацій, презентації лекцій. Вже видано навчальні посібники, створено тематичні відеофільми на різну тематику та лазерні компакт-диски. Всіма джерелами інформації студенти можуть користуватися на кафедральній WEB-сторінці в Інтранеті. Окрім того, майбутні лікарі мають вільний доступ до бібліотеки авторефератів MEDLINE. Отож у розпорядженні студентів $є$ суттєвий обсяг навчального матеріалу, який дозволяє отримати якісні теоретичні знання під час підготовки до практичних занять.

(c) Н. А. Ничик 
Для визначення найінформативніших навчальних матеріалів з інфекційних хвороб, якими користуються студенти під час самопідготовки до практичних занять, було проведено анкетування старшокурсників (5 та 6 курси). Отримані результати наведено у таблиці 1.

Таблиця 1. Результати анкетування студентів

\begin{tabular}{|l|c|c|c|c|c|c|c|c|c|c|}
\hline \multirow{2}{*}{ Джерело інформації } & \multicolumn{7}{|c|}{ Частота використання, \% } \\
\cline { 2 - 14 } & \multicolumn{2}{|c|}{ завжди } & \multicolumn{2}{|c|}{ часто } & \multicolumn{2}{c|}{ періодично } & \multicolumn{2}{c|}{ рідко } & \multicolumn{3}{c|}{ ніколи } \\
\cline { 2 - 13 } & 5 курс & 6 курс & 5 курс & 6 курс & 5 курс & 6 курс & 5 курс & 6 курс & 5 курс & 6 курс \\
\hline $\begin{array}{l}\text { Матеріали для підготовки до } \\
\text { практичного заняття }\end{array}$ & 44,6 & 21,2 & 42,9 & 26,5 & 7,1 & 15,6 & 3,6 & 29,1 & 1,8 & 7,6 \\
\hline $\begin{array}{l}\text { Матеріали для підготовки до } \\
\text { лекцій }\end{array}$ & 8,9 & 14,5 & 7,1 & 24,6 & 17,9 & 28,5 & 44,6 & 28,8 & 39,3 & 3,6 \\
\hline Презентації лекцій & 10,7 & 36,9 & 37,5 & 32,4 & 23,2 & 25,6 & 21,4 & 7,3 & 7,1 & 2,0 \\
\hline Навчальні відеофільми & 1,8 & 37,1 & 8,9 & 29,2 & 21,4 & 17,3 & 37,5 & 10,3 & 30,4 & 6,1 \\
\hline Навчальні посібники & 44,6 & 25,6 & 26,8 & 23,4 & 14,3 & 19,8 & 5,4 & 30,1 & 8,9 & 1,1 \\
\hline Атлас з інфекційних хвороб & 3,6 & 42,1 & 3,6 & 29,7 & 14,3 & 15,4 & 33,9 & 10,2 & 44,6 & 2,6 \\
\hline Методичні рекомендації & 17,8 & 29,3 & 28,6 & 34,1 & 16,1 & 15,9 & 23,2 & 12,5 & 14,3 & 8,2 \\
\hline $\begin{array}{l}\text { Навчальні лазерні компакт- } \\
\text { диски }\end{array}$ & 1,8 & 35,7 & - & 29,3 & 1,8 & 32,2 & 7,1 & 1,2 & 89,3 & 1,6 \\
\hline $\begin{array}{l}\text { Бібліотека авторефератів } \\
\text { МЕDLINЕ }\end{array}$ & 1,8 & 26,4 & - & 27,6 & 1,8 & 35,8 & 16,0 & 10,2 & 80,4 & 1,0 \\
\hline
\end{tabular}

Аналіз отриманих результатів виявив, що студенти 5-го курсу під час підготовки теми найчастіше користуються матеріалами до практичних занять і навчальними посібниками, що дозволяє їм отримати грунтовну теоретичну базу. Рідше звертаються за інформацією до навчальних відеофільмів. Вкрай рідко вивчаються матеріали бібліотеки MEDLINE, лазерні компакт-диски та інші електронні джерела (електронні книги з інфекційних хвороб, медичні журнали, наукові статті). Як правило, такими джерелами користуються члени студентського наукового гуртка. Отже, викладачам під час створення матеріалів для студентів 5-го курсу варто особливу увагу приділяти якості та інформативності саме теоретичної бази, яка б дозволяла студентам оптимально підготуватися до практичного заняття.

Під час аналізу даних, отриманих в результаті анкетування студентів 6-го курсу, встановлено, що під час підготовки до практичного заняття вони найчастіше звертаються до презентацій лекцій, атласу 3 інфекційних хвороб, навчальних відеофільмів та лазерних компакт-дисків, користуються також матеріалами бібліотеки MEDLINE. Отож студенти, які

\section{Література}

1. Впровадження кредитно-модульної системи організації навчального процесу у ВМ(Ф)НЗ України : матеріали Всеукраїнської навч.-наук. конф. $з$ міжнар. участю. - Тернопіль : ТДМУ, 2010. -494 с.

2. Васько Л. В. Використання сучасних електронних технологій для вивчення курсу гістології, цитології та ембріо- після 5-го курсу мають відповідні теоретичні знання, готові закріплювати та удосконалювати їх на практиці і, відповідно, ставати освіченими фахівцями.

Висновки. Встановлено, що студенти 5-го курсу приділяють більшу увагу опрацюванню теоретичних матеріалів, тоді як шестикурсники найчастіше звертаються до джерел, що містять наочну інформацію (відеофільми, компакт-диски, атлас 3 інфекційних хвороб).

Отже, зважаючи на високий відсоток самостійної роботи студентів в Інтранеті і використання під час самостійної підготовки матеріалів, розміщених на WEB-сторінці кафедри, вважаємо, що інформація до практичних занять повинна обов'язково регулярно переглядатися авторами і систематично поновлюватися новими науковими даними. Згідно з проведеним аналізом, встановлено, що для студентів 5-го курсу варто більш детальну інформацію подавати під час створення теоретичних матеріалів, а для шестикурсників доцільно максимально розкрити практичну частину заняття. Такий підхід дозволить сформувати майбутніх лікарів 3 потужною теоретичною підготовкою і логічним клінічним мисленням.

логії / Л. В. Васько, В. І. Бумейстер, Л. І. Кіптенко // Вісник проблем біології і медицини. -2011.-Вип. 2, Т. 1.-С. 20.

3. Авдеєнко А. П. Інтенсифікація навчального процесу та організація самостійної роботи / А. П. Авдеєнко, Л. В. Дементій, О. С. Поляков // Проблеми освіти : [наук.метод. зб.]. -К. : НМКВО, 2001.-Вип. 24.-С. 108-110. 